\title{
Sustainable Urban Development: Building Healthy Cities in Indonesia
}

Author 1 Linda DARMAJANTI, Urban Development Studies, Universitas Indonesia; Indonesia

Author 2 Daniel Mambo TAMPI, Architecture Engineering, National Institute of Science and Technology; Indonesia

Author 3 Irene Sondang FITRINITIA, Urban Development Studies, Universitas Indonesia; Indonesia

\begin{abstract}
The urban process or commonly called urbanization is a phenomenon that is occurring in several regions in Indonesia. In 2045, the projection results show $61.7 \%$ of Indonesia's population will live in urban areas. In the process, cities in Indonesia are facing several challenges related to Urban Infrastructure, decent and affordable housing, clean environment, local economic, slum, and urban poor (Social welfare). These indicators can have a positive impact on increasing the city index with healthy city categories, but also can have a negative impact with the increasing gap between the poor and the rich. The purposes of this study are to find out which cities in Indonesia fall into the category of healthy cities and to find out what factors and actors play a role in building healthy cities in Indonesia. The analytical method in this study is log frame analysis. The result is building healthy cities is closely related to the availability of aspects of life in urban areas: health services, environmental, and socioeconomic aspects. There are 3 cities in Indonesia: Palembang, Solo and Denpasar City. Building a healthy city is also an effort in improving health status, health facilities, cleanliness, garbage services, food availability, clean water, security, safety, park facilities, public transportation, art and culture facilities, housing, urban economics, religious facilities, and urban planning quality. Healthy cities in Indonesia will be achieved if efforts to improve not only physical health but also mental, social, economic and spiritual health are achieved. Finally, building a healthy city in Indonesia is an effort to contribute to sustainable urban development.
\end{abstract}

\section{Keywords}

Urbanization, Healthy City, Urban Development, Sustainable

\section{Introduction}

\subsection{Subheading 1.1}

Healthy cities are cities that continue to create and improve the quality of the physical and social environment and expand community resources that enable people to support one another. To carry out all functions of life and develop the maximum potential of society (Glouberman, 2014). To realize a healthy city, an approach that is in accordance with the urgency of the city's problems is needed. In the urban context, urbanization is an issue that cannot be released and will continue, especially in cities in developing countries. This phenomenon is related to increasing population and the extent of the city's physical 
development. Rapid growth and development requires the city to prepare and organize various facilities that can support activities in urban areas.

Based on the projection results in Indonesia, in $2045,67.1 \%$ of the population will live in urban areas (Ministry of National Development Planning, 2019). In the process, urbanization produces many impacts on the aspects of infrastructure, socio-economic and environment. The impact also adds to the long list of problems with the issue of the low quality of human life in urban areas. This is motivated by the unpreparedness of cities to provide basic needs of the community as a result of the process of urbanization. The basic needs includes in the form of inadequate housing prices, low quality of clean air and water, security, employment and other supporting facilities. The easiest thing to see regard the health issue in city is the pollution issue have been occurred in Jakarta for these past two weeks (Jakarta Post, July, 2019). Achieving a good quality air in Jakarta has been very challenging since the transportation mode in Jakarta less integrated. Even there is a "newcomer" MRT, but the effect still does not give a big effect to air status in Jakarta. Since the real time indexed and Greenpeace had announced that Jakarta being heavy polluted according the World Health Organization (WHO) standards which known as PM2.5. It was above the WHO's safe limit of 10 micrograms per cubic meter $(\mu \mathrm{g} / \mathrm{m} 3)$. This particle is very harmful if come into human respiratory system and the human body. Vehicle engines, industry, wood and coal burning becomes source that exacerbated the atmosphere. Therefore, city dwellers face a clear and present enemy called air pollution.

Another thing is the existence of contagious tropical disease while mosquito become vector of the dengue fever. Since the urbanization dense the area with the built up area, it eliminate the mosquitos habitant and could trigger the distribution of dengue fever. More than 2,000 people in Indonesia's capital Jakarta have been diagnosed with dengue fever in January this year, with one person confirmed killed by the mosquito-borne disease (Strait Times, March 2019)

Currently these challenges are faced by cities in Indonesia. If these things are not immediately corrected and their quality is improved, the consequence is that there is a gap /inequality development between the poor and the rich. This will also hamper efforts in realizing sustainable urban development. The following is a projection of the Indonesian population in metropolitan cities.

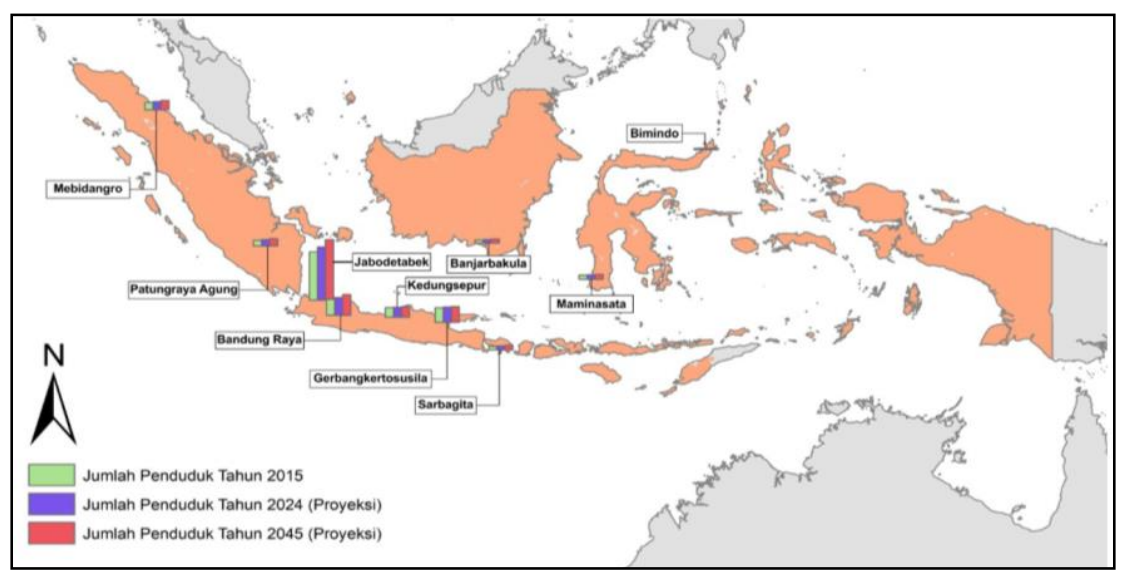

Figure 1. The Projection of The Indonesian Population in Metropolitan Cities

(Source: Ministry of National Development Planning, 2019) 
Figure 1. Indicates that there is an increase in the number of residents in 2 periods of 20 years between 2015-2024 and 2024-2045. The Jabodetabek area is an urban area that is superior in terms of population, followed by Bandung Raya, and Gerbangkertasusila. The metropolitan cities above need to pay attention to the challenges of urbanization by building a healthy city concept. In addition, it should be noted that aspects must be improved by looking at the city index based on aspects of security, safety, health, health facilities, cleanliness, solid waste, the city's economy, food sufficiency, quality of city parks, clean water services (IAP, 2017). These aspects are a support in building a healthy city.

The WHO measurement, until the Ministry of Health Index and Livability City Index. The concept of a healthy city involves two important aspects, namely place and people in addition to improving the quality of the physical environment, healthy cities also play a role to improve the quality of human life, ensure the welfare of the urban community, and access for all. The purpose of writing this article is to find important factors and actors in building healthy cities and any city that is ready to implement a healthy city. The concept of a healthy city is also part of efforts to realize sustainable city development.

\section{Materials and Method}

\subsection{Materials}

The Healthy cities concept focuses on the process, not just the outcome. It is obvious from the definition that a Healthy City requires a continuous development process that has no end point. It is not necessarily one that has achieved a particular health status. It is conscious of health as an urban issue and is striving to improve it. Any city can be a Healthy City if it is committed to health and has a structure and process to work for its improvement (Department of Health, Hongkong, 2007)

The Healthy Cities approach emphasizes the way that the city environment (conceived very broadly) influences the health of residents. This approach explicitly acknowledges the diversity and interconnectedness of the many elements of urban living. It is a holistic approach that assumes that everything within a community is connected, and cities therefore need to get many sectors involved in developing public health policies. (Glouberman, 2014). In their approach to healthy cities, "health" includes not only physical health, but also mental, social, economic, political, and spiritual health. They list the following 11 features of a healthy city: 1) A clean, safe, high-quality physical environment (including housing quality). 2) An ecosystem that is stable now and sustainable in the long term. 3) A strong, mutually supportive, and non-exploitative community. 4) A high degree of public participation in and control over the decisions affecting one's life, health, and wellbeing. 5) The meeting of basic needs (food, water, shelter, income, safety, and work) for all the city's residents. 6) Access to a wide variety of experiences and resources with the possibility of multiple contacts, interaction, and communication. 7) A diverse, vital, and innovative city economy. 8) Encouragement of connectedness with the past, with the cultural and biological heritage, and with other groups and individuals. 9) A city form that is compatible with and enhances the above parameters and behaviours. 10) An optimum level of appropriate public health and sick care services accessible to all. 11) High health status (both high positive health status and low disease status). This list serves as a guideline for cities participating in the Healthy Cities movement, sponsored by the World Health Organization. Hancock and Duhl in Gloubermen (2014) also emphasized the importance of the involvement of local governments in health promotion. 
In addition to the factors in building healthy cities in Indonesia, the previous factors are also related to Several Missions in Sustainable City Management in Indonesia, namely Mission 2 Livable and Inclusive, Mission 3 Advanced Cities, Green City Missions in order to Manage of metropolitan cities in Indonesia. Mission 2 Providing basic service access for every resident to basic services (a.l. settlement, transportation, drinking water, sanitation). Healthy city planning should be viewed as healthy urban planning and readily connect the two into a more holistic approach to improve the health and lives of communities. (Portney, 2017). Using planning to achieve healthier cities occurs at the intersection of two disciplines. Although having a history of collaboration, and having common roots, the two disciplines have built-up working practices that make joint working difficult (Arthurson, Lawless \& Hammet in Grant, 2019). A simple caricature of the two disciplines would be:

- Public health: Population level interventions focused on people.

- Planning: Population level interventions focused on place.

Of course, in reality public health can be concerned with place and environment, but in other instances having just a narrow focus on the individual. An approach for using the physical planning and design of cities was specifically developed within the World Health Organization (WHO) European Network of Healthy Cities. This initiative began in 1988, and is still continuing today, with phase VII launched in 2018. Each phase lasts about five years, with cities across the WHO European region eligible to apply phase by phase (Grant, 2019).

Sustainable urban development seeks to create cities and towns that improve the long-term health of the planet's human and ecological systems. It assigns human and ecological systems equal importance, and implies that the health of both is interdependent. (Wheeler, 1996)

\subsection{Method}

The method of data collection in this article is a literature study of healthy city concepts, using livable city index IAP 2017 and the management mission of sustainable cities in Indonesia. The analysis in this article is to use the log -frame analysis method. To answer the first goal, namely modifying data based on city index that is feasible for 2017 IAP, selecting several indicators related to the concept of a healthy city then selecting 3 cities with the highest number of indexes. To answer the second goal in this study is to analyze what needs to be improved in developing healthy cities based on the concept of healthy cities in developing countries that are integrated with factors in the city index that is feasible for 2017 IAP, and analyze who the actors / stakeholders play a role in cities that are close to the criteria for healthy cities, namely Palembang, Solo and Denpasar City. At the end of the analysis, triangulation of data will be displayed to explain the purpose, theory, methodology, analysis, result and source of data.

\section{Result and Discussion}

\subsection{Cities with Healthy City Index}

The following is a healthy city index indicator table taken from the 2017 Livable city index IAP book, there are 16 indicators chosen in terms of building healthy city concepts namely security, safety, health, health facilities, cleanliness, garbage services, urban economics, food, housing, park facilities, clean water, transportation, art and cultural facilities, public participation, religious services and urban planning quality. The following is a healthy city index table in Indonesia. 
Table 1.Indonesia Health City Index

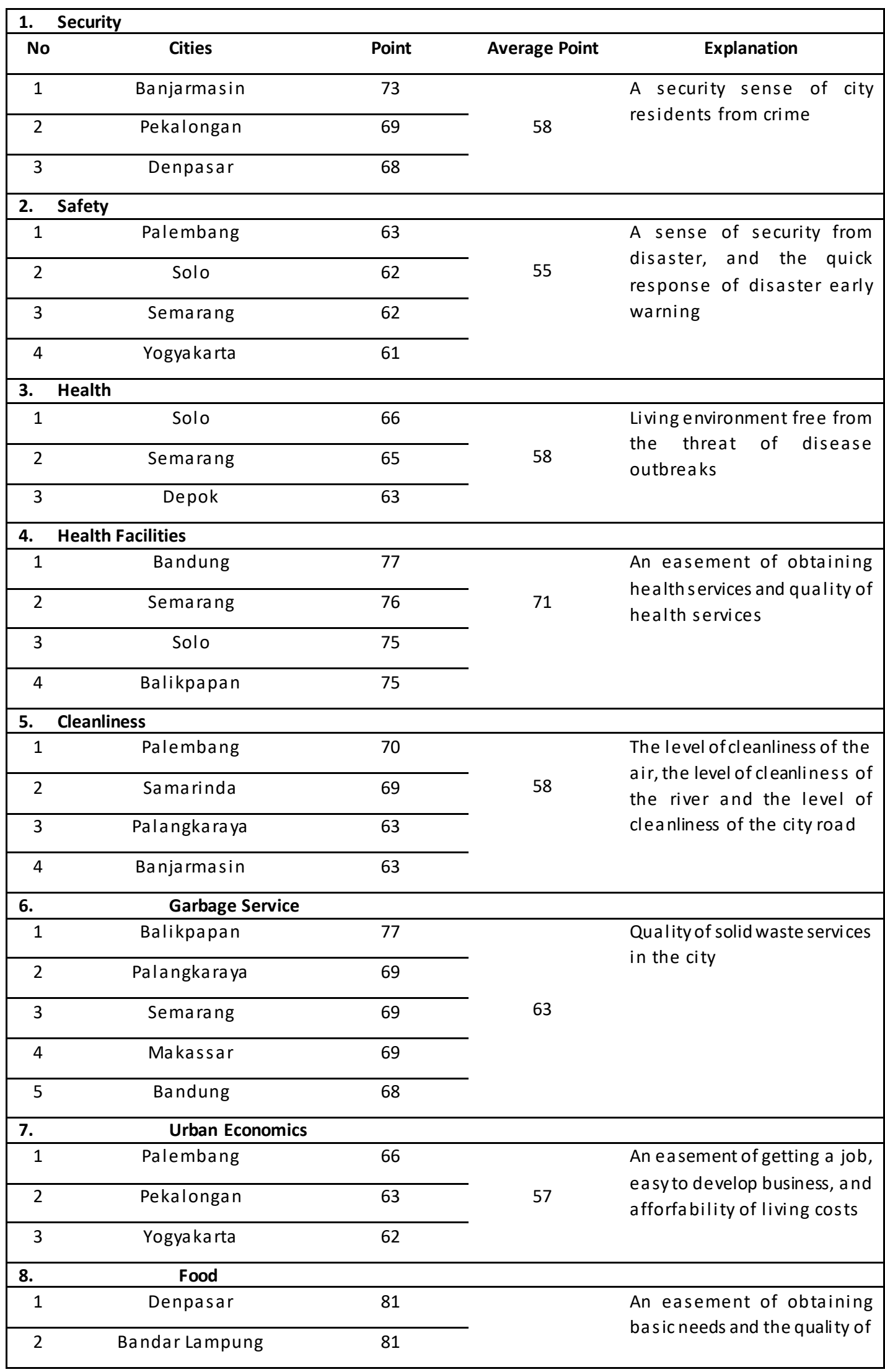




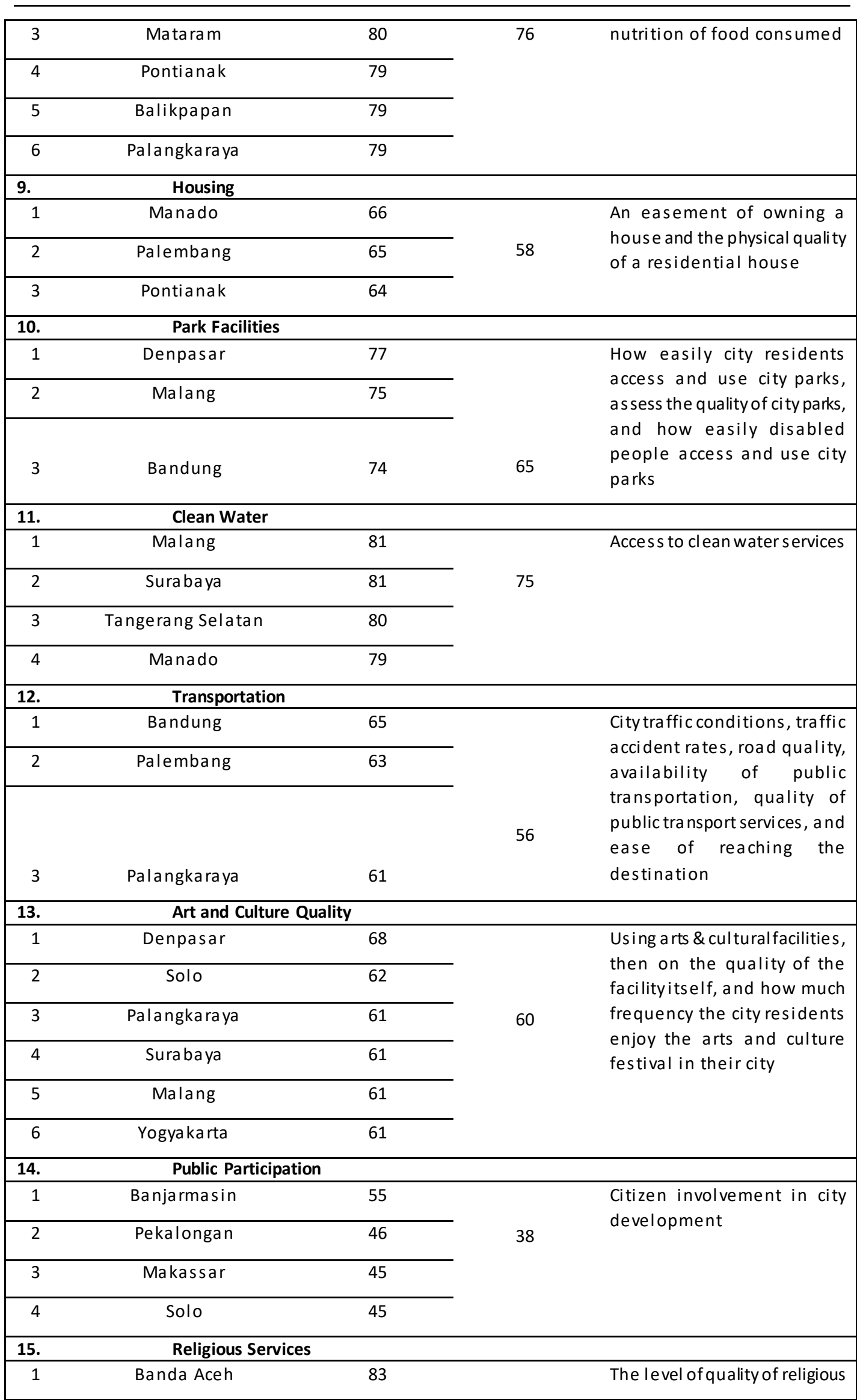




\begin{tabular}{|ccccc|}
\hline 2 & Manado & & 56 & services in the city \\
\hline 3 & Pontianak & 82 & & \\
\hline 4 & Banjarmasin & 81 & & \\
\hline 16. & Urban Planning Quality & & & \\
\hline 1 & Makassar & 76 & & \\
\hline 3 & Palembang & 74 & & \\
\hline 3 & Bandung & 71 & & \\
\hline
\end{tabular}

Source: Modified from IAP Livable City Index, 2017

Based on the 16 Indicators above, there are 3 cities with the top indices which can be categorized as cities that are ready to go to a healthy city. These cities are Palembang, Solo and Denpasar. The city of Palembang is superior to 7 indicators, namely Safety, Cleanliness, Solid Waste Service, City Economy, Housing, Transportation, and Quality of City Planning. The City of Solo excels at 5 Indicators, namely Safety, Health and City Health Facilities, Arts and Culture Facilities, and Public Participation, Denpasar City excels at 4 Indicators namely Security, Food, Garden Facilities, and Arts and Culture Facilities. The following is a list of the top 3 cities that have been processed based on 16 livable city index indicators for IAP 2017.

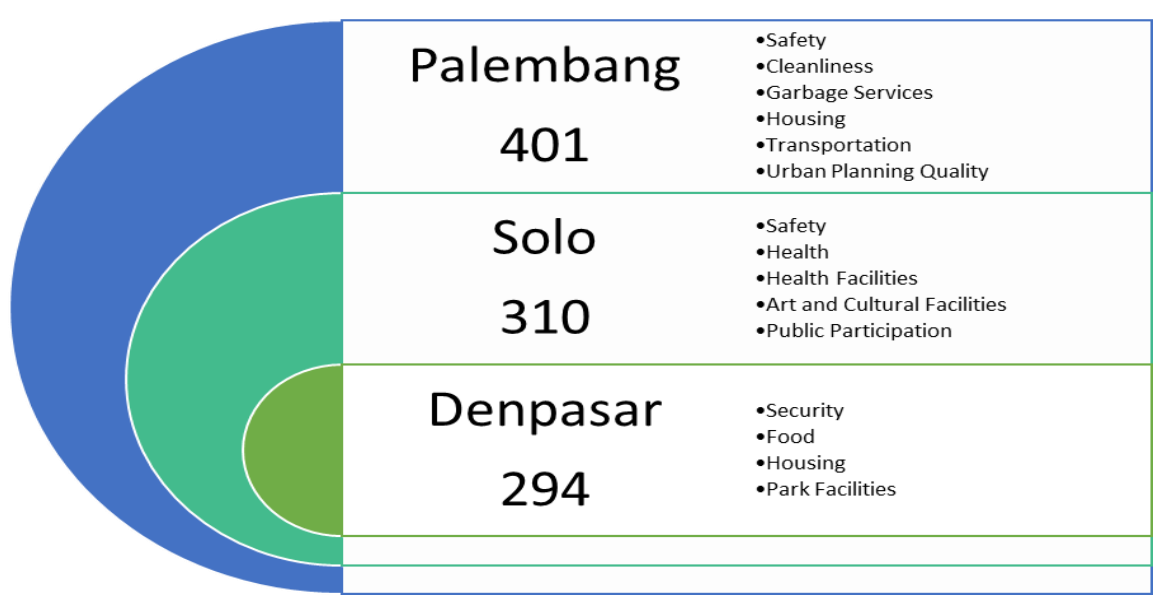

Figure 2. Top 3 Toward Healthy Cities in Indonesia (Source: Private Process, 2019)

Figure 2. describes the 3 cities in the top list of several healthy city concept criteria. Although it is still far from the concept of a healthy city, this is a good step to continue to improve the quality of the places and activities of people who live in the city. There is no maximum quality limit in building a healthy city. Building a healthy city is a process that must be sustainable because it will be related to the issue and dynamic. To continue the ongoing process, it is necessary for actors who play an important role in realizing a healthy city in Indonesia. The strategy in building healthy cities in Indonesia will be outlined in the logframe analysis table which contains how to achieve nobel aim, goal and purpose.

\subsection{Factor and Actor of Building Healthy City in Indonesia}

The following is a log-frame analysis framework table that explains the description of nobel aim, goal and purpose in building healthy cities in Indonesia 
Table 2. Log-frame Analysis Building Healthy Cities in Indonesia

\begin{tabular}{|c|c|c|c|c|}
\hline No & Noble Aim & & & \\
\hline & $\begin{array}{l}\text { Building Healthy } \\
\text { Cities in Indonesia }\end{array}$ & & & \\
\hline & Goal & Factor & & $\begin{array}{l}\text { Important } \\
\text { Assumptions }\end{array}$ \\
\hline 1 & $\begin{array}{l}\text { Increasing Place and } \\
\text { Environment Quality }\end{array}$ & $\begin{array}{l}\text { Health facilities, } \\
\text { Cleanliness, Garbage } \\
\text { Services, Housing, Park } \\
\text { Facilities, } \\
\text { Transportation, Art \& } \\
\text { Cultural Quality and } \\
\text { Urban Planning Quality }\end{array}$ & & $\begin{array}{l}\text { By increasing the index } \\
\text { on these factors it is } \\
\text { assumed that it can } \\
\text { improve the quality of } \\
\text { the place and the city } \\
\text { environment }\end{array}$ \\
\hline 2 & People & $\begin{array}{l}\text { Health, Security, Safety, } \\
\text { Urban Economics, } \\
\text { Food, Clean Water, } \\
\text { Park Facilities, } \\
\text { Transportation, Artand } \\
\text { Cultural Quality, } \\
\text { Religious Services, } \\
\text { Public Participation }\end{array}$ & & $\begin{array}{l}\text { Increasing the index on } \\
\text { these factors is } \\
\text { assumed to increase } \\
\text { people quality }\end{array}$ \\
\hline & Purpose & Measurement & Actor & $\begin{array}{c}\text { Important } \\
\text { Assumptions }\end{array}$ \\
\hline 1 & Health facilities & $\begin{array}{l}\text { The ease of getting } \\
\text { Health Services }\end{array}$ & City Health Agency & $\begin{array}{l}\text { Assumed to reach goal } \\
1\end{array}$ \\
\hline 2 & $\begin{array}{l}\text { Cleanliness, Garbage } \\
\text { Services, } \quad \text { Park } \\
\text { Facilities }\end{array}$ & $\begin{array}{l}\text { The level of cleanliness } \\
\text { of the air, the level of } \\
\text { cleanliness of the river, } \\
\text { and the level of } \\
\text { cleanliness of the city } \\
\text { road }\end{array}$ & $\begin{array}{l}\text { City Sanitation and } \\
\text { Landscaping Office } \\
\text { and Environmental } \\
\text { Agency }\end{array}$ & $\begin{array}{l}\text { Assumed to reach goal } \\
1\end{array}$ \\
\hline 3 & Housing & $\begin{array}{l}\text { The ease of owning a } \\
\text { house and the physical } \\
\text { quality of a residential } \\
\text { house }\end{array}$ & $\begin{array}{l}\text { Public Housing Agency } \\
\text { and Settlement Area }\end{array}$ & $\begin{array}{l}\text { Assumed to reach goal } \\
1\end{array}$ \\
\hline
\end{tabular}




\begin{tabular}{|c|c|c|c|c|}
\hline 4 & Transportation & $\begin{array}{l}\text { City traffic conditions, } \\
\text { traffic accident rates, } \\
\text { road quality, a vailability } \\
\text { of public transport. }\end{array}$ & $\begin{array}{l}\text { Department of } \\
\text { Transportation }\end{array}$ & $\begin{array}{l}\text { Assumed to reach goal } \\
1\end{array}$ \\
\hline 5 & Art \& Cultural Quality & $\begin{array}{l}\text { Use arts \& cultural } \\
\text { facilities, then towards } \\
\text { the quality of the } \\
\text { facilityitself }\end{array}$ & $\begin{array}{l}\text { Culture and Tourism } \\
\text { Agency }\end{array}$ & $\begin{array}{l}\text { Assumed to reach goal } \\
1\end{array}$ \\
\hline 6 & $\begin{array}{ll}\text { Urban } & \text { Planning } \\
\text { Quality } & \end{array}$ & $\begin{array}{l}\text { General city quality in } \\
\text { the city }\end{array}$ & $\begin{array}{l}\text { Cipta Karya, Spatial } \\
\text { Planning and Land } \\
\text { Agency }\end{array}$ & $\begin{array}{l}\text { Assumed to reach goal } \\
1\end{array}$ \\
\hline 7 & Health & $\begin{array}{l}\text { The living environment } \\
\text { is free from the threat } \\
\text { of disease outbreaks }\end{array}$ & $\begin{array}{l}\text { Health and } \\
\text { Environmental Agency }\end{array}$ & $\begin{array}{l}\text { Assumed to reach goal } \\
2\end{array}$ \\
\hline 8 & Security & $\begin{array}{l}\text { The security of the city } \\
\text { residents from crime or } \\
\text { crime }\end{array}$ & Regional Police & $\begin{array}{l}\text { Assumed to reach goal } \\
2\end{array}$ \\
\hline 9 & Safety & $\begin{array}{l}\text { A sense of security } \\
\text { from disasters, and the } \\
\text { speed of disaster early } \\
\text { warning }\end{array}$ & $\begin{array}{l}\text { Regional Disaster } \\
\text { Management Agency, } \\
\text { Meteorology and } \\
\text { Geophysics Agency }\end{array}$ & $\begin{array}{l}\text { Assumed to reach goal } \\
2\end{array}$ \\
\hline 10 & Urban Economics & $\begin{array}{l}\text { Ease of getting a job, } \\
\text { ease of business } \\
\text { development, and } \\
\text { affordability of living } \\
\text { costs }\end{array}$ & $\begin{array}{l}\text { People's Economic } \\
\text { Agency }\end{array}$ & $\begin{array}{l}\text { Assumed to reach goal } \\
2\end{array}$ \\
\hline 11 & Food & $\begin{array}{l}\text { The ease of getting } \\
\text { basic food and the } \\
\text { nutritional quality of } \\
\text { food consumed }\end{array}$ & $\begin{array}{l}\text { Agriculture and Health } \\
\text { Agency }\end{array}$ & $\begin{array}{l}\text { Assumed to reach goal } \\
2\end{array}$ \\
\hline 12 & Clean Water & $\begin{array}{l}\text { Access to clean water } \\
\text { services }\end{array}$ & $\begin{array}{l}\text { Environment and } \\
\text { Public Works Agency }\end{array}$ & $\begin{array}{l}\text { Assumed to reach goal } \\
2\end{array}$ \\
\hline 13 & Park Facilities & $\begin{array}{l}\text { How easily disabled } \\
\text { people access and use } \\
\text { city parks }\end{array}$ & $\begin{array}{l}\text { Agency of Sanitation } \\
\text { and City Parks and } \\
\text { Social Service }\end{array}$ & $\begin{array}{l}\text { Assumed to reach goal } \\
2\end{array}$ \\
\hline
\end{tabular}




\begin{tabular}{|c|c|c|c|c|}
\hline 14 & Transportation & $\begin{array}{l}\text { The quality of public } \\
\text { transport services, and } \\
\text { the ease of reaching } \\
\text { the destination }\end{array}$ & $\begin{array}{l}\text { Department of } \\
\text { Transportation }\end{array}$ & $\begin{array}{l}\text { As sumed to reach goal } \\
2\end{array}$ \\
\hline 15 & Art \& Cultural Quality & $\begin{array}{l}\text { How much frequency } \\
\text { do cityresidents enjoy } \\
\text { art and culture festivals } \\
\text { in the city }\end{array}$ & $\begin{array}{l}\text { Cultural and tourism } \\
\text { agency }\end{array}$ & $\begin{array}{l}\text { Assumed to reach goal } \\
2\end{array}$ \\
\hline 16 & Religious Services & $\begin{array}{l}\text { The level of quality of } \\
\text { religious services in the } \\
\text { city }\end{array}$ & Religious Service & $\begin{array}{l}\text { Assumed to reach goal } \\
2\end{array}$ \\
\hline 17 & Public Participation & $\begin{array}{l}\text { Citizen involvement in } \\
\text { city development }\end{array}$ & $\begin{array}{l}\text { All Services and All } \\
\text { Elements of the } \\
\text { Citizen }\end{array}$ & $\begin{array}{l}\text { Assumed to reach goal } \\
2\end{array}$ \\
\hline
\end{tabular}

Table 2. Describes the description of log-frame analysis on how to build healthy cities in Indonesia. The nobel aim of the log-frame analysis is to build healthy cities in Indonesia. To achieve the nobel aim, there are two goals, namely place and people. To achieve the goal place, The index is needed on 8 factors, assuming to increase the index of those factors, the quality of the place and the environment of the city will improved. To achieve the goal of people, The index is needed on 11 factors, assuming that increasing the index on those factors is assumed to increase people quality.

Each goal has actors who play a role in building a healthy city for the first goal, the actors who play a role are the City Health Agency, City Sanitation and Parks Service as well as the Environment Service, Public Housing and Settlement Services, Transportation and Transportation Agency, Cultural and Tourism, Cipta Karya, Spatial Planning and Land Agency. Then, the actors who play a role in the two people 's Goal, namely the Health Service and the Environmental Service, Regional Police, Regional Disaster Management Agency, Meteorology and Geophysics Agency, People's Economy Service, Agriculture Service and Health Service, Environmental Service and Public Works Service, Sanitation Service and City Parks as well as the Social Service, Transportation and Transportation Agency, Culture and Tourism Agency, Religious Services and all Services and All Elements of the City Community.

Finally Building a healthy city is also in line with the sustainable city development mission carried out by the ministry of planning and national development in Mission 2 Livable and Inclusive, Mission 3 Advanced Cities, Green Cities in Management of metropolitan cities in Indonesia. Sustainable city development will continue to run in accordance with the concept of sustainable city development that has been conveyed earlier that Sustainable urban development is like that to improve the long-term health of the planet's human and ecological systems. It assigns human and ecological systems equal importance, and implies that the health of both is interdependent. The following is a table of triangulation in writing this article 
Table 3. Triangulation

\begin{tabular}{|c|c|c|c|c|c|}
\hline No & Tujuan & Theory & $\begin{array}{c}\text { Methodology \& } \\
\text { Analysis }\end{array}$ & Result & Source of Data \\
\hline 1 & $\begin{array}{l}\text { Cities with High } \\
\text { Index (Heal thy } \\
\text { Cities Criteria) }\end{array}$ & $\begin{array}{l}\text { Hancockand Duhl, } \\
\text { Glouberman }\end{array}$ & $\begin{array}{l}\text { Choosing } 3 \text { Cities } \\
\text { by calculating } \\
\text { index on each } \\
\text { factor, Descriptive } \\
\text { Analysis }\end{array}$ & $\begin{array}{l}\text { - } \quad \text { Palembang } \\
401 \text { points } \\
\text { - Solo } 310 \\
\text { points } \\
\text { Denpasar } 294 \\
\text { points }\end{array}$ & $\begin{array}{l}\text { IAP Livable City } \\
\text { Index 2017, } \\
\text { Personal } \\
\text { Statement, } \\
\text { Personal } \\
\text { Modification }\end{array}$ \\
\hline 2 & $\begin{array}{l}\text { Factor and } \\
\text { Actor }\end{array}$ & $\begin{array}{l}\text { United Nation, } \\
\text { WHO, Ministry of } \\
\text { National } \\
\text { Development } \\
\text { Planning, Grant, } \\
\text { Portney }\end{array}$ & $\begin{array}{l}\text { The factors are } \\
\text { divided into } 2 \\
\text { goals, the actors } \\
\text { based on their } \\
\text { responsibility to } \\
\text { deal with and } \\
\text { using Log-frame } \\
\text { analysis }\end{array}$ & $\begin{array}{l}\text { Factors: Place, } \\
\text { Environment and } \\
\text { People } \\
\text { Actor, Government } \\
\text { and Citizen }\end{array}$ & $\begin{array}{l}\text { IAP Livable City } \\
\text { Index 2017, } \\
\text { Personal } \\
\text { Statement, } \\
\text { Personal } \\
\text { Modification }\end{array}$ \\
\hline
\end{tabular}

Source: Personal Modified, 2019

Table 3. Shows triangulation of data on the objectives achieved, namely top 3 with high index, factor and actor. This discussion uses the theory of Hancock and Duhl, United Nation, WHO, Ministry of National Development Planning, Grant and Portney. The analytical method used is Choosing 3 Cities by calculating the index on each factor, Descriptive Analysis. The factors are divided into 2 goals, the actors based on their responsibility to deal with and use Log-frame analysis. The results of the first goal obtained were that there were 3 cities with the highest index in relation to the concepts of healthy cities namely Palembang, Solo and Denpasar. The second result is factors that are divided into two goals, namely place and people. The source of data comes from IAP Livable City Index 2017, Personal Statement and Personal Modification.

\section{Conclusion}

To deal with various urban challenges in Indonesia, various innovations and quality improvements are needed, especially in building healthy cities. Based on the analysis, it was concluded that building healthy cities in Indonesia requires 16 factors, namely safety, health, health facilities, cleanliness, garbage services, urban economics, food, housing, park facilities, clean water, transportation, art and cultural facilities, public participation, religious services and urban planning quality. The importance of the role of actors is also needed. Such actors are like the relevant government agencies and the community as beneficiaries as well as those responsible for maintaining the quality of the factors. Furthermore, based on the results of the analysis, there are 3 cities with the highest indexed that can be categorized as cities that are ready to go to healthy cities, namely Palembang, Solo and Denpasar City. 
Each of these cities still needs to increase the index on factors that have not reached the average index.

To develop the concept of a healthy city, it is not only focused on human (individuals) but also concerns people who live in cities or public health. Healthy city is not only physical health but also mental, social, economic and spiritual health are achieved. In addition to people, the concept of a healthy city also focuses on place, namely improving the ecological system and quality of the city. Finally, building a healthy city in Indonesia is a continuous and interdependent process through cross actors and cross factors to realizing Sustainable Urban Development.

\section{Acknowledgment}

The Congress and Young Planning Professional Workshop fee was funded by Citilink Urban Asia Ltd, 100 Jervois Street, Sheu Wang, Central District, Hongkong. Special Thanks for Sebastian Goethals, Vice President of ISOCARP who has supported me in order to participate in The Congress and YPP Workshop in Jakarta and Bogor 2019.

\section{References}

Department of Health (2007) Building Healthy Cities: Guidelines for Implementing A Healthy Cities Project in Hongkong, Hongkong

Glouberman, Sholom. Newman Chaylm (2014) A Framework For Improving Health in Cities: A Discussion Paper. Journal of Urban Health: Bulletin of the New York Academy of Medicine, Vol. 83, No. 2. New York, United States.

Grant, Marcus (2019) Planning for Healthy Cities, https://www.researchgate.net/publication/326399922, Springer, Accessed on 30 July 2019

Indonesian Association of Planners. 2017. Indonesia Livable City Index. Jakarta: Indonesia

Jakarta Post (2019) New Study Links Exposure to Air Pollution with Lung Aging and Increased Risk of Chronic Lung Disease Risk, https://www.thejakartapost.com/life/2019/07/10/new-study-links-exposure-to-airpollution-with-lung-aging-and-increased-risk-of-chronic-lung-disease-risk.html, accessed on 9 July 2019.

Ministry of National Development Planning (2019) Sustainable Metropolitan Management. PPT National Seminar on Urban Sustainable and Regional Development, Jakarta, Indonesia.

Portney, Kent. Sansom, Garret Thomas (2017) Sustainable Cities and Healthy Cities: Are They the Same?, Urban Planning (ISSN: 2183-7635) 2017, Volume 2, Issue 3, Pages 45-55. Lisbon, Portugal.

Strait Times (2019) Dengue Fever Infects More Than 2,000 People in Jakarta, kills one, https://www.straitstimes.com/asia/se-asia/dengue-fever-infects-more-than-2,000people-in-jakarta-kills-one, accessed on 9 July 2019 
Wheeler, Stephen (1996) Sustainable Urban Development: A Literature Review and Analysis. IURD Monograph Series: UC Barkeley 